\title{
Characterization of the Tank 41H Saltcake Insoluble Solids
}

iby

D. T. Hobbs

Westinghouse Savannah River Company

Savannah River Site

Aiken, South Carolina 29808

DOE Contract No. DE-AC09-89SR18035

This paper was prepared in connection with work done under the above contract number with the U.S. Department of Energy. By acceptance of this paper, the publisher and/or recipient acknowledges the U.S. Government's right to retain a nonexclusive, royalty-free license in and to any copyright covering this paper, along with the right to reproduce and to authorize others to reproduce all or part of the copyrighted paper.

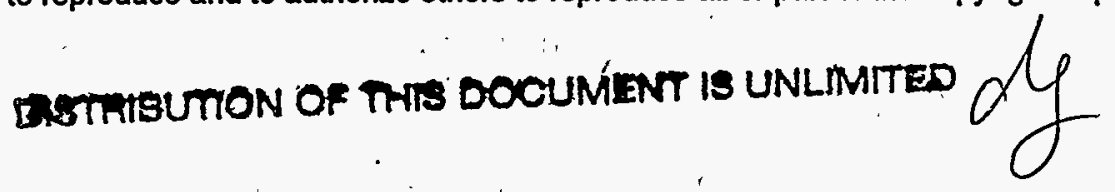




\section{DISCLAIMER}

This report was prepared as an account of work sponsored by an agency of the United States Government. Neither the United States Government nor any agency thereof, nor any of their employees, makes any warranty, express or implied, or assumes any legal liability or responsibility for the accuracy, completeness, or usefulness of any information, apparatus, product, or process disclosed, or represents that its use would not infringe privately owned rights. Reference herein to any specific commercial product, process, or service by trade name, trademark, manufacturer, or otherwise does not necessarily constitute or imply its endorsement, recommendation, or favoring by the United States Government or any agency thereof. The views and opinions of authors expressed herein do not necessarily state or reflect those of the United States Government or any agency thereof.

This report has been reproduced directly from the best available copy.

Available to DOE and DOE contractors from the Office of Scientific and Technical Information, P.O. Box 62, Oak Ridge, TN 37831; prices available from (615) 576-8401.

Available to the public from the National Technical Information Service, U.S. Department of Commerce, 5285 Port Royal Road, Springfield, VA 22161.

\section{RECEIVED}

MAR 041998

으.ST 


\section{DISCLAIMER}

Portions of this document may be illegible electronic image products. Images are produced from the best available original document. 
From: D. T. Hobbs, 773-A

Technical Reviewer:

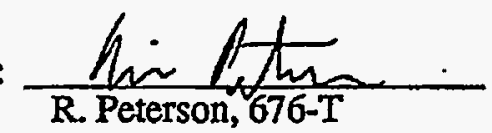

\section{Characterization of the Tank 41H Saltcake Insoluble Solids (U)}

\section{SUMMARY}

The particle sizes of the insoluble solids from two of the Tank $41 \mathrm{H}$ saltcake samples have been determined by scanning electron microscopy. Settling velocities of the solids have been calculated using Stokes' Law. Based on these settling velocities, it is concluded that uranium cannot be segregated from the bulk of the insoluble solids during salt dissolution operations by gravity settling. Selective dissolution of uranium and neutron absorbers (e.g., $\mathrm{Cr}, \mathrm{Fe}, \mathrm{Mn}$, and $\mathrm{Zn}$ ) was not observed upon contacting the insoluble solids briefly with $0.015 \mathrm{M} \mathrm{NaOH}$ solution and for six days with deionized, distilled water. Thus, it is concluded that the formation of a solid phase consisting of uranium without significant amounts of $\mathrm{Cr}, \mathrm{Fe}, \mathrm{Mn}$, and $\mathrm{Zn}$ is not possible during the dissolution of saltcake.

\section{INTRODUCTION}

Dissolution of saltcake stored in Tank 41H is scheduled to be initiated during FY95. The resulting salt solution will be transferred to In-Tank Precipitation (ITP) for waste processing. A total of four saltcake samples have been taken from the top of the tank and analyzed for chemical and radiochemical content. Approximately 1 wt $\%$ of the samples were determined to be comprised of solids that do not readily dissolve in inhibited water $(0.015 \mathrm{M} \mathrm{NaOH})[1,2]$. Although the solids contain fissile isotopes of uranium and plutonium, the concentration of fissile material is well below that to be of concern for nuclear criticality safety. However, during a safety review of salt dissolution, questions arose conceming the possibility of the fissile material separating from the bulk of the insoluble solids and accumulating in a separate layer in the tank. Therefore, samples of the insoluble solids from the saltcake samples were isolated and characterized by Scanning Electron Microscopy (SEM) to deternine the particle sizes and distribution of uranium. Settling velocities were then calculated based on the measured particle sizes. The insoluble solids were also contacted for 3-6 days with deionized, distilled water to determine if significant changes in the particle size, uranium and other neutron absorbers content would occur upon prolonged contact with unsaturated aqueous solution. 


\section{EXPERIMENTAL}

Sufficient material from Tank $41 \mathrm{H}$ saltcake samples $\# 2-1$ and $\$ 2-3$ were available for characterization: A measured quantity of saltcake from each sample was placed in a glass centrifuge tube in the Shielded Cells of 773-A. Twenty-five milliliters of $0.015 \mathrm{M}$ sodium hydroxide solution (inhibited water) was added to each sample to dissolve the watersoluble solids. After dissolution was judged to be complete by visual observation that no further dissolution of solids was occurring, the tubes were centrifuged for 30 minutes. The clear solution was decanted from the undissolved solids and placed in a clean polyethylene bottle. The solids were rinsed with three $10 \mathrm{~mL}$ portions of inhibited water. After each rinse, the tubes were centrifuged for 30 minutes, and the rinse water decanted from the undissolved solids. A fourth rinse was performed on the \#2-1 sample because of the larger solids content. The final rinse solution from each sample was submitted for uranium and elemental analyses.

The undissolved solids were transferred to a radiohood in laboratory module B-126/130. Each sample was suspended in $2 \mathrm{~mL}$ of deionized, distilled water ( $\mathrm{pH}=5.6$ ). Small portions of the suspended solids were placed on lens paper and allowed to air dry. SEM mounts containing double-sided tape were contacted with the dry solids to transfer solids onto the mount. The mounts were transferred to the SEM laboratory and analyzed. Two mounts were prepared for each sample. After three days, a second set of mounts were prepared as described above. The objective of preparing the second set of mounts was to determine if soaking the solids in deionized, distilled water would result in significant changes to the particle size and distribution of uranium. After 6 days, the deionized, distilled water was decanted from the undissolved solids and submitted for uranium analysis by kinetic phosphorescence spectroscopy and elemental analysis by inductivelycoupled plasma emission spectroscopy.

\section{RESULTS AND DISCUSSION}

\section{SEM Results}

1. General Particle Morphology, Elemental Composition, and Size Characteristics The bulk of the insoluble solids were observed to be comprised of irregular-shaped solids from 1 to $10 \mu \mathrm{m}$ in diameter. A small fraction of particles having spherical, nectangular, and hexagonal shapes were also observed. The larger rectangular particles, $15-200 \mu \mathrm{m}$ in diameter, were thin.

Elements identified in the solids included: $\mathrm{Cr}, \mathrm{Fe}, \mathrm{Al}, \mathrm{Si}, \mathrm{Na}, \mathrm{Ca}, \mathrm{Zn}, \mathrm{P}$, and $\mathrm{U}$. These elements are consistent with previous results from inductively-coupled plasma emission spectroscopy and inductively-coupled plasma mass spectrometry $[1,2]$. Micrographs of the solids after soaking in the deionized, distilled water for three days did not indicate any significant changes in the particle size, morphology or elemental composition.

\section{Particle Size Measurements}

Particle diameters were measured from the micrographs obtained for each of the samples. Table I gives the average particle diameter as well as the smallest and largest diameters for each sample. The majority of the solids particles are comprised of particles ranging in diameter from about $1 \mu \mathrm{m}$ to $10 \mu \mathrm{m}$. Both samples contained a small number of Iarger particles ranging in diameter from $14 \mu \mathrm{m}$ to $91 \mu \mathrm{m}$ (number average of $43 \mu \mathrm{m}$ ) for sample $\# 2-1$ and $18 \mu \mathrm{m}$ to $190 \mu \mathrm{m}$ (number average of $96 \mu \mathrm{m}$ ) for sample $\# 2-3$. A small number of particles containing uranium were also detected. The number average particle diameter of these particles was determined to be $6.6 \mu \mathrm{m}$ for sample $\# 2-1$ and $4.9 \mu \mathrm{m}$ for \#2-3. The uranium-rich particles ranged in diameter from 1.4 to $12 \mu \mathrm{m}$. 
Table I. Average Particle Sizes for the Tank 414 Saltcake Insoluble Solids

\begin{tabular}{cccccc} 
& & \multicolumn{3}{c}{ Particle Diameter $(\mu \mathrm{m})$} \\
Sample ID & ADS \# & & Average $^{\mathrm{a}}$ & Minimum & Maximum \\
\#2-1 & $3-38820$ & 2.9 & 1.2 & 8.5 \\
\#2-1 After Soaking & $3-38821$ & 3.6 & 1.5 & 7.9 \\
\#2-3 & $3-38822$ & 2.8 & 0.9 & 9.5 \\
\#2-3 After Soaking & $3-38823$ & & 2.7 & 0.9 & 9.3 \\
\cline { 4 - 5 } & & & & anumber average
\end{tabular}

Settling Velocities Settling velocities in solutions of varying density and viscosity were calculated using Stokes' Law

$$
V=2 g\left(d_{s}-d_{1}\right) r^{2} / 9 n
$$

where $V$ is the settling velocity in $\mathrm{cm} / \mathrm{sec}$, $g$ is the gravitational constant $\left(980 \mathrm{~cm} / \mathrm{sec}^{2}\right)$, $d_{s}$ is the particle density in $g / \mathrm{cm}^{3}, d_{1}$ is the solution density in $g / \mathrm{cm}^{3}, r$ is the radius of the particle in $\mathrm{cm}$, and $\mathrm{n}$ is the viscosity of the solution in poises.

Based on the dissolution of Tank $19 \mathrm{~F}$ salt, salt solution densities would be expected to range between 1.2 and $1.4 \mathrm{~g} / \mathrm{cm}$ during the dissolution of saltcake in Tank $41 \mathrm{H} \mathrm{[3].} \mathrm{As}$ salt dissolves, the density of the sait solution increases as does the viscosity. Karraker previously measured the viscosities (3.5-12.5 cP) of salt solutions over similar density ranges (1.28-1.42 $\left.\mathrm{g} / \mathrm{cm}^{3}\right)$, as well as the particle density for $\mathrm{Na}_{2} \mathrm{U}_{2} \mathrm{O}_{7}[4]$. The crystalline densities of solid phases identified in the Tank 41H insoluble solids range from 1.75 to $5.7 \mathrm{~g} / \mathrm{cm}^{3}[2]$. Using the crystalline densities to bound the range of of particle densities for the bulk insoluble solids, a particle density of 3.93 for the uranium solids [4], the previously reported salt solution viscosities and densities [4], and the measured particle diameters from the SEM results, the settling velocities for the insoluble solids were calculated. The minimum and maximum settling velocities for the uranium-rich particles and the bulk insoluble solids in the Tank 41H saltcake samples are given in Table II.

\section{Table H. Settling. Velocities for Uranium and Bulk Solid Particles in Tank 4IH Saltcake}

Particle.Description

Uranium particle of average diameter

Uranium particle of smallest diameter

Uranium particle of largest diameter

Bulk particle of average diameter

Bulk particle of smallest diameter

Bulk particle of largest diameter

Settling Velocity (in/day) Minimum Maximum

8.9

0.73

54 .

0.38

0.040

450
34

2.8

200

20

1.9

21000 
For the range of uranium-rich particle diameters observed in the Tank $41 \mathrm{H}$ insoluble solids, the settling velocities range from 0.73 in/day to 200 in/day. For the bulk of the insoluble solids the settling velocities are calculated to range from 0.040 to 21000 in/day. The wide range is a result of primarily the wide range in particle sizes $(0.9-96 \mu \mathrm{m})$, and to a lesser degree, the range in the particle densities $\left(1.75-5.7 \mathrm{~g} / \mathrm{cm}^{3}\right)$ and the variation in solution density $\left(1.28-1.42 \mathrm{~g} / \mathrm{cm}^{3}\right)$ and viscosity $(3.5-13.3 \mathrm{cP})$. Based on the calculated settling velocities, it is concluded that segregation of the uranium-rich particles from the bulk solids is not possible by gravity settling since the settling velocities of the bulk insoluble solids bound those of the uranium particles.

Analytical Results for Rinse and Soak Solutions The final inhibited water rinse solution and the deionized, distilled water soak solution were submitted for measurement of uranium and elemental composition. The uranium, chromium, iron, manganese, and zinc concentrations for each solution are provided in Table III.

Table III. Uranium and Neutron Absorber Concentrations. in Final Rinse and Soak Solutions

\begin{tabular}{|c|c|c|c|c|c|}
\hline \multirow[b]{3}{*}{ Element } & \multicolumn{5}{|c|}{ Concentration (mg/L) } \\
\hline & \multicolumn{2}{|c|}{ \#2-1 } & \multicolumn{3}{|c|}{ \#2.3 } \\
\hline & Final Rinse & Soak Solution & & Final Rinse & Soak Ślution \\
\hline U & 0.082 & 0.18 & 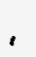 & 0.038 & 0.18 \\
\hline Cr & 9.87 & 30.4 & & 7.95 & 8.84 \\
\hline $\mathrm{Fe}$ & 0.82 & 3.38 & & 1.07 & 1.88 \\
\hline $\mathrm{Mn}$ & 0.038 & $<0.091$ & & 0.032 & $<0.091$ \\
\hline $\mathrm{Zn}$ & 0.26 & 1.04 & & 3.07 . & 3.16 \\
\hline
\end{tabular}

The percent of total dissolved was calculated for $\mathrm{U}, \mathrm{Cr}, \mathrm{Fe}, \mathrm{Mn}$, and $\mathrm{Zn}$ in each solution along with the mole ratio of each element to that of uranium for the insoluble solids and each of the solutions. The results are provided in Table IV.

For both samples, the percent of uranium and the other elements removed in the soak solution is less than that found in the final rinse solution. This indicates that the removal of uranium and the other elements from the solids is not significantly increased although the initial $\mathrm{pH}$ of the solution is much lower (initial $\mathrm{pH}$ of soak solution is 5.6 versus a calculated $\mathrm{pH}$ for the rinse solution of 12.2) and the contact time increased from approximately 90 minutes to six days. The final.pH of the soak solution was not measured, but would be higher than 5.6 due to the presence of residual rinse solution.

The mole ratio of the various elements to uranium are similar for both the final rinse and soak solutions. This indicates that there is not significant preferential dissolution of any of the elements over the wide range in $\mathrm{pH}$. For sample \#2-1, the mole ratios in the rinse and soak solutions are all higher than that determined in the insoluble solids with the exception of $\mathrm{Mn}$. This indicates that these elements are removed in concentration relative to that of $U$ in the insoluble solids. However, the extent of removal is not sufficient to significantly change the mole ratios after rinsing and soaking. For sample $\$ 2-3$, the mole ratios in the rinse and soak solutions are all lower than that determined in the insoluble 
solids. Thus, it is concluded that the formation of a solid phase consisting of uranium without significant amounts of $\mathrm{Cr}, \mathrm{Fe}, \mathrm{Mn}$, and $\mathrm{Zn}$ is not possible during the dissolution of saltcake.

Table IV. Percent of Total Dissolved and Mole Ratio of Absorbers to Uranium

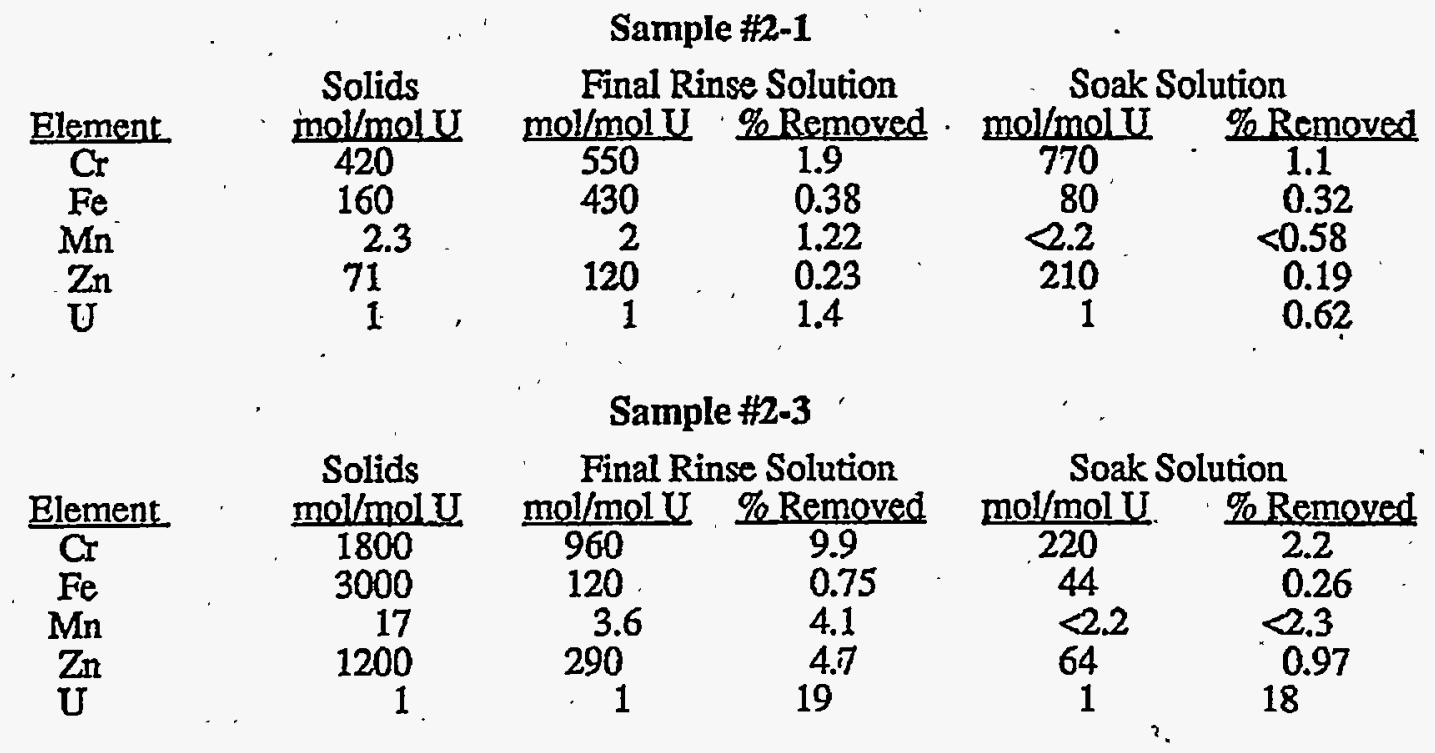

QUALITY ASSURANCE

The handling and analysis of the samples were performed in accondance with the requirements specified in the Task and Quality Assurance Plan[5]. Due to the limited quantity of saltcake, only a single subsample of samples \#2-1 and \#2-3 could be analyzed. All laboratory data are recorded in laboratory notebook, WSRC-NB-93-151, maintained by $D$. T. Hobbs.

\section{REFERENCES}

1. D. T. Hobbs , C. J. Coleman, and R. N. Mahannah, "Final Report: Analysis of Tank 41H Saltcake Sample \#1," WSRC-TR-93-277, August 20, 1993.

2. D. T. Hobbs and C. J. Coleman, "Final Report: Analysis of Tank 41H Saltcake Sample \#2 and Comparison to Sample \#1," WSRC-TR-94-057, January 26, 1994.

3. A. Q. Goslen, "Tank 19 Salt Removal," DPSP-84-17-7, August, 1986.

4. D. G. Karraker, "Uranium Settling Rates in SRS Waste Supernate," WSRC-TR-94058, January 26, 1994.

5. D. T. Hobbs, "Task and Quality Assurance Plan for the Analysis of Tank 41H Saltcake Samples (U)," WSRC-RP-93-495, rev. 0, March 28, 1993. 
cc: T. M. Monahon, 703-H

R. A. Scaggs, 703-H

R. G. Croley, 241-120H

R. Boyleston, 241-152H

J. N. Brooke, 719-4A

W. E. VanPelt, 241-152H

J. E. Marra, 703-H

M. C. Chandler, 703-H

W. L. Tamosaitis, 773-A

A. L. Blancett, 773-A

W. S. Cavin, 773-A

P. F. Cloessner, 773-A

D. D. Walker, 773-A

M. J. Barnes, 773-A

D. G. Karraker, 773-A

R. Peterson, 676-T

F. Trumble, 786-1A

J. R. Chandler, 773-24A TIM, 703-43A

IWT-LWP File, 773-A 